\title{
Municipal solid waste management practices in inner cities of Osogbo, Osun State and its implications on health
}

\author{
*Bello T.B ${ }^{1}$, Kolawole T.D ${ }^{1}$, Jesuleye F.A ${ }^{1}$, Ogunola E.O ${ }^{1}$, Oyebode M.O ${ }^{1}$, Abraham O. D ${ }^{1}$, \\ Olaniyi R.O ${ }^{1}$ and Bamigbayan I.O ${ }^{1}$
}

\begin{abstract}
Background: Indiscriminate waste disposal is a common practice in many cities of Sub-Saharan Africa and these unhealthy practices have made the region face severe environmental deterioration and health implications. The objective of this study is to assess the association between waste management practices and self-reported health outcomes among inner city dwellers in Osogbo.
\end{abstract}

Method: The study is a cross sectional study carried out among 351 household heads using a semistructured interviewer administered questionnaire.

Results: Majority (78.6\%) of respondents had poor practice of waste management although, most showed concern on likely impacts of poor waste management. Most of them $(81.8 \%)$ demonstrated positive attitude towards waste management and were willing to participate in organized waste management at low cost. Gender $\left(X^{2}=7.217, P<0.05\right)$, income $\left(X^{2}=12.140, P<0.05\right)$, occupation $\left(X^{2}=29.034, P<0.05\right)$ and level of education were significantly associated with their poor waste management practices. Majority (74\%) reported at least one ill health condition, practice and attitude were the major variables implicated in various ill health reported by the respondents.

Conclusion: Poor waste management practices are strongly associated with ill health.

Keywords: Solid Waste, Management, Self-reported health outcomes, Practices.

\author{
*Corresponding author \\ Bello T.B. \\ ORCID-NO: http://orcid.org/0000-0001-2471-617X \\ Email: temilade.bello@uniosun.edu,ng \\ ${ }^{1}$ Department of Community Medicine, Osun State University, Osogbo, Osun State, Nigeria
}




\title{
Pratiques de gestion des déchets solides municipaux dans les centres- villes d'Osogbo, Osun State et ses implications sur la santé
}

\author{
*Bello T.B ${ }^{1}$, Kolawole T.D ${ }^{1}$, Jesuleye F.A ${ }^{1}$, Ogunola E.O ${ }^{1}$, Oyebode M.O ${ }^{1}$, Abraham O. D \\ Olaniyi R.O ${ }^{1}$ and Bamigbayan I.O ${ }^{1}$
}

\begin{abstract}
Résumé
Contexte général de l'étude : L'élimination sans discernement des déchets est une pratique courante dans de nombreuses villes d'Afrique subsaharienne et ces pratiques malsaines ont fait en sorte que la région est confrontée à une grave détérioration de l'environnement et à des implications pour la santé. L'objectif de cette étude est d'évaluer l'association entre les pratiques de gestion des déchets et les résultats de santé auto déclarés chez les habitants du centre-ville d'Osogbo.
\end{abstract}

Méthode de l'étude : L'étude est une étude transversale menée auprès de 351 chefs de ménage à l'aide d'un questionnaire semi-structuré administré par un enquêteur.

Résultats de l'étude : La majorité $(78,6 \%)$ des répondants avaient une mauvaise pratique de la gestion des déchets, bien que la plupart se soient montrés préoccupés par les impacts probables d'une mauvaise gestion des déchets. La plupart d'entre eux $(81,8 \%)$ ont manifesté une attitude positive envers la gestion des déchets et étaient prêts à participer à une gestion organisée des déchets à faible coût. $\operatorname{Sexe}(X 2=7,217$, $\mathrm{P}<0,05)$, revenu $(\mathrm{X} 2=12,140, \mathbf{P}<0,05)$, profession $=29,034, \mathrm{P}<0,05)$ et le niveau d'éducation étaient significativement associés à leurs mauvaises pratiques de gestion des déchets. La majorité (74\%) a signalé au moins un problème de santé, la pratique et l'attitude étaient les principales variables impliquées dans divers problèmes de santé signalés par les répondants.

Conclusion : De mauvaises pratiques de gestion des déchets sont fortement associées à une mauvaise santé.

Mots-clés : Déchets solides, gestion, résultats de santé auto déclarés, pratiques.

\section{*Corresponding author}

Bello T.B.

ORCID-NO: http://orcid.org/0000-0001-2471-617X

Email: temilade.bello@uniosun.edu,ng

${ }^{1}$ Department of Community Medicine, Osun State University, Osogbo, Osun State, Nigeria 


\section{INTRODUCTION}

Solid waste management (SWM) is a well-known environmental issue for urban communities in both developed and developing countries. It has been established that factors such as economic boom, population growth. rapid urbanization and improvement in living standard contribute largely to municipal solid waste generation in developing countries (1). The issue of solid waste management is more critical in the metropolis of many low-income countries, which are confronted with rapid and unplanned urbanization as well as a high incidence of poverty (2). It was also reported (3) that the health of residents of poor country's cities are threatened by inadequate water supply and sanitation facilities, poor and overcrowded housing, smoky kitchens, insect infestation, contaminated food, piles of uncollected garbage and poor drainage. Management of solid waste in developing countries is worsened by unsustainable practices such as open dumping in uncontrolled sites, open burning and mismanagement of the leachate produced in final disposal sites which enhances environmental contamination and spread of diseases (4). All these threaten the wellbeing of urban inhabitants via the spread of communicable diseases and compromised aesthetics (5).

Indiscriminate dumping has become a common method of waste disposal in many cities of Sub-Saharan Africa and these unhealthy practices has made the region face severe environmental deterioration and health implications (6). The dumpsite is an ideal breeding ground for disease vectors such as rats and mosquitoes which present serious health issues to nearby household residents. Such unsanitary environment is a predisposing factor for the spread of diseases like malaria, dengue fever, typhoid, tetanus, cholera, eczema, and dysentery (7). Peculiar to slums in low-income countries is poor physical infrastructure complicated by uncontrolled disposal in open spaces near water bodies thus constituting a public health nuisance (8). Study (9) has stated that inner city is a category of slum owned by the urban middle or high classes but has been vacated due to improved socio-economic status and now occupied by the urban poor and the new city entrants. Understanding such community practices towards solid waste management and their willingness to adopt a sustainable management option thus becomes critical for informing necessary interventions This study therefore sought to document waste management practices and identify likely factors responsible for self-reported health outcomes among inner city dwellers in Osogbo.

\section{MATERIALS AND METHOD Description of Study Area}

Osogbo is the capital of Osun State in southwestern part of Nigeria. The city has a population of about 156,694 people according to 2006 census and it's also one of those cities characterized by rapid urbanization. The Ministry of Environment and Waste Management Agency are situated within the city. The two local government areas in the city also comprise of various communities that can be well described as inner cities. These inner cities are primarily inhabited by low-income earners, petty traders, artisans and unemployed. Among these communities are Oja Oba, Oke-Baale and Oluode. Osogbo like many other cities in Nigeria is characterized by rapid urbanization and population growth, with attendant challenges in waste management and sanitation issues. The city consists of several inner cities which are characterized by inappropriate waste disposal and unsanitary environments.

\section{Studydesign}

A cross sectional descriptive survey was carried out among 351 household heads using Leslie Fisher's formular for sample size calculation and, following a multistage sampling procedure. The instrument used for data collection was a semi structured questionnaire. The questionnaire which was divided into sections to capture data on socio demographic characteristics, municipal solid waste management practices, attitude and concern toward solid waste management, willingness to partake in an organized solid waste management and perceived health outcome, was used to obtain information from the subjects. Adult heads who have lived for over six months within the community were included while those who did not consent to participating were excluded.

\section{Data management}

Data collected from the study was processed and analyzed using Statistical Package for Service Solution (IBM SPSS V23) and values were considered statistically significant at pvalue less than 0.05 . Eleven questions were computed for attitude with minimum and maximum score at 2 and 7 respectively while mean score stood at 6 (based on calculated average). Similarly, six questions were computed 
for practice with minimum and maximum score at 0 and 6 respectively while mean score stood at 3 (based on calculated average). Attitude score below mean score were computed as negative attitude while practice score below mean score were computed as poor practice respectively. Health outcomes were categorized by pooling all report of at least one health outcome as "Yes" and no health outcome as "No". Chi-square test was used to determine the association between two categorical variables while Binary logistic regression was used to determine the predictive factors of health outcomes. Values were considered statistically significant at $\mathrm{P}$-value less than 0.05 .

Ethical consideration: Ethical permission was sought from Health Research Ethical Committee of Osun State University, Osogbo. The questionnaire used in the study was an anonymous one and respondent's consent was sought before data collection.

\section{RESULTS}

Socio demographic variables of the respondents are presented in Table 1 below, the average age of the respondents is 43 years with more of respondents in the age range of 25 to 39 years. Majority $(76.9 \%)$ of the respondents are females while most $(83.8 \%)$ are married. Most $(73.8 \%)$ of the respondents are Muslims while only about one-fifth (19.9\%) did not pass through a formal school setting. Majority $(91.5 \%)$ of them are skilled workers working with government or rendering one professional service or the other. About half of them (46.7\%) earn below 10,000 naira while very few earn above 21,000 naira monthly.

\section{Concerns of respondents towards improper solid waste management}

Respondents' concerns towards improper solid waste management are presented in Table 3. A larger percentage $(83.8 \%)$ of the respondents agreed that improper solid waste management practices will have negative effect on natural resources and majority $(94.0 \%)$ of the respondents also affirmed that improper solid waste management will result in health-related risks due to open burning. Majority (93.4\%) of them believe improper management will result in flooding due to blockage of drainage. While most $(90.3 \%)$ believe it will result in pollution of water bodies, almost all of them (97.2\%) affirmed that improper solid waste management practices will cause offensive odor in the environment, only few $(10.5 \%)$ of the respondents felt that improper solid waste management practices do not lead to proliferation of disease vector

\section{Willingness of respondents to partake in organized solid waste management}

Respondents' willingness to participate in organized solid waste management is presented in Table 5. Majority (70.7\%) of the respondents are willing to participate in organized solid waste management but a little above half $(54.7 \%)$ are not willing to separate their waste. Although, majority (70.4\%) of the respondents are willing to pay for solid waste collection from their household, a larger percentage $(71.2 \%)$ of the respondents are willing to pay between a hundred (\#100.00) naira and one thousand (\#1000.00) naira monthly.

\section{Self-reported health outcomes}

Table 6 shows the results of self-reported health outcomes of the respondents in the last six months. Within a period of six months, over twothirds $(70.9 \%)$ of the respondents reported coming down with malaria, nearly a third (30.2\%) reported coming down with typhoid, about four fifths $(83.2 \%)$ reported vomiting without fever, about one quarter $(26.8 \%)$ reported skin infections, over a quarter $(27.6 \%)$ came down with diarrhea while about one-fifth reported respiratory infections.

Categorized health outcomes, categorized practices, and categorized attitude towards solid waste management

Figures 1, 2 and 3 are representations of categorized health outcomes, practices and attitude of respondents. Generally, majority (74\%) of the respondents reported one health issue or the other within the last six months. Although, majority $(78.6 \%)$ of the respondents demonstrated poor practices towards solid waste management, most of them $(81.8 \%)$ had positive attitude towards it.

Relationship between selected sociodemographic variables and categorized practice Associations between selected sociodemographic variables and practices of respondents are presented in Table 7 . Gender, occupation, income, and educational level showed significant association $(\mathrm{P}<0.05)$ with practices of respondents towards solid waste management. 


\section{Relationship between self-reported health outcomes and selected variables}

Association between self-reported health outcomes and selected factors is presented in Table 8. The results showed that practice and attitude towards solid waste management were significantly associated with self-reported health outcomes.

\section{Predictive factors of health outcomes of respondents}

A logistic regression model found that attitude and practice towards waste management were the major independent factors responsible for health outcomes among the respondents in this study. Respondents with poor practice were 2.27 times more likely than those with good practice to report negative health outcomes. Similarly, respondents with negative attitude were 3.45 more likely to develop negative health outcomes than those with positive attitude.

\section{DISCUSSION}

Majority of the respondents $(78.6 \%)$ in this study having poor practices of waste management may not be unconnected with the characteristics of such environments. Usually, urban slums are densely populated, dirty, and characterized by high rate of social vices and poverty. Even though, respondents generally showed concern over various likely negative impacts of improper waste management and demonstrated positive attitude towards it, their practices do not correspond to their attitude and concern. Their poor practices may be attributed to the fact that majority of them are low-income earners and priority is placed more on food and shelter. This is evident from their responses pertaining to willingness to partake in organized waste collection as majority are willing to pay for such services but only willing to pay between 100 and 1000 naira per month. It is evident from the average income of less than 20,000 naira realized by majority $(86.7 \%)$ of the respondents on monthly basis that this class of people may not be able to afford a good living and sanitary conditions. This could largely be the reason why majority of this low-income earners resulted to dwell in slums. According to studies (10-12), poverty coupled with acute housing deficit play crucial roles in the emergence of slums in developing nations. Majority of inner-city dwellers are so poor that their little income cannot support them with decent living. Hence, they are forced to eke out a livelihood from all sorts of meagre income generating activities.
Observation of majority of respondents in this study showed they do not sort their wastes and larger percentage of the few that engage in sorting does so to feed their domestic animals. It is a very common habit of Nigerian slum dwellers to cohabit with their domestic animals such as goat, sheep, cats, dogs, and chickens. Due to high poverty level, they rear these animals to generate more income for the family and feed them with the edible biodegradable components of their wastes. Although, a good number of them practice open dumping, majority claimed to use organized waste collectors. The use of organized waste collector is a viable option for majority of slum dwellers in Osogbo because Osun state waste management agency has been very effective in the clean-up of waste across the city. Thus, it is not impossible this service is made use of by majority in the city owing to the efforts of the state government in this regard.

Similar to previous studies (13-15), gender, occupation, educational level and monthly income exhibited a positive relationship with household waste practices in this study. More females $(81.9 \%)$ had poor practice compared to males $(67.9 \%)$ and more $(80.7 \%)$ of unskilled workers had poor practice than the skilled $(56.7 \%)$. This direction of relationship may not be unexpected as females are traditionally generators and managers of household waste materials in this part of the world. Also, the skilled workers are more likely to have basic education, more enlightened and informed than the unskilled and this probably affected their decision towards better waste management practices. Similarly, more of respondents without formal education $(91.4 \%)$ had poor practices compared to their counterparts (75.4\%) and this may be because the educated ones are able to take better decisions on issues of their health and environment. Level of education, occupations and monthly income could be good determinants of waste management practices as these factors go a long way to influence once thinking and decisions on certain health or environmental issues. In a related study (16), the author observed that generation of solid waste was influenced by family size, education level, and income among other factors.

Although this study may be limited by not accounting for other confounding factors such as lifestyles and nutritional status among others, documented cases of some diseases in the study area may be linked to consequences of bad practices of waste management such as open 
dumping, dumping in water drains exhibited by some respondents which could lead to proliferation of disease-causing organisms. As seen in this study that, more of people with bad practices $(76.4 \%)$ had health outcomes compared to their counterpart $(64.0 \%)$, more of those with negative attitude $(89.1 \%)$ also had health outcomes as compared to those with positive attitude $(70.4 \%)$. Waste management practice is a key factor in disease prevention. For instance, it was reported (17) that waste management practices which include illegal burying in areas not legally designated as waste dump sites used by slum dwellers are usually carried out on cultivable areas and dwelling areas thus leading to deterioration of land, as well as ground and surface water contamination. All these happen due to proximity of the dump sites to places of residence. Similar study (18) has also documented relationship between residential proximity to environmental wastes and adverse health outcomes. The author demonstrated a significant correlation between residential proximity to environmental wastes and risks for central nervous system defects, congenital heart defects, oral defects, low birth weight, cancer, leukaemia, asthma, chronic respiratory symptoms, etc. Poor management of solid waste has been found to contribute to flooding, air pollution, and spread of diseases and health conditions such as respiratory ailments and diarrhoea, and these problems have been found more severe particularly in slums in developing countries where solid waste management systems are inadequate $(19,20)$.

\section{CONCLUSION}

This study reveals that, although the respondents are slum dwellers, majority showed concern on likely impacts of poor waste management, demonstrated positive attitude towards waste management and were willing to participate in organized waste management at a low cost. However, despite these, majority of them recorded poor practices towards waste management. While gender, income, occupation and level of education were significantly associated with poor practice of the respondents, practice and attitude were the major variables implicated in various ill health conditions recorded by the respondents. To improve respondents' waste management practices, government should sustain and improve on existing waste collection procedure while relevant stakeholders embark on health promotion and education strategies targeted at behavioral changes.

Conflict of interest: The authors declare no conflict of interest

\section{References}

1. Minghua Z F, Xiumin A, Rovetta H, Qichang F, Vicentini L, Bingkai A, Giusti LY. Municipal solid waste management in Pudong new area, China. Waste Manage. 2009; 29 (3):1227-1233.

2. Coban A, Ertis I F, Cavdaroglu NA. Municipal solid waste management via multi criteria decision-making methods: A case study in Istanbul, Turkey. J. Clean. Prod. 2018; 180: 159-167.

3. Songsore J. Urbanization and health in Africa: Exploring the interconnections between poverty, inequality and the burden of disease. Accra: Ghana Universities Press. 2004.

4. Kubanza N S, Das D K, Simatele D. Some happy, others sad: Exploring Environmental Justice in Solid Waste Management in Kinshasa, The Democratic Republic of Congo. Local Environ. 2017; 722 (5): 595-620.

5. Simatele M, Etambakonga C L. Scavenging for solid waste in Kinshasa: A livelihood strategy for the urban poor in the Democratic Republic of Congo. Habitat Int. 2015; 49; 1-58

6. Komolafe S F. Sustainable Solid Waste Management - A Possible Solution to Environmental and Sanitation Problems in the Ancient City of Ibadan, Nigeria. Journal of Environ. Sci. Technol. 2011; 4: 119-22

7. Manaf L A., Samah M A A, Zukki N I M. Municipal solid waste management in Malaysia: Practices and challenges. Waste Manag. 2009; 29:2902-2906.

8. Makinde O O. Housing: Central City Slums, A Case Study of Ibadan. Journal of Environ. Earth Sci. 2012;2 (9);21-31.

9. World Bank. Upgrading Low Income Urban Settlements Country Assessment Report. Accra: Ghana Publishing Corporation. 2002.

10. Hari S. Poverty and Slums, Its Impact of Changing Economic Landscape. South 19 Asia: Analysis Groups Co Ltd. 2006.

11. Njoku C and Okoro G.C. Urban renewal in Nigeria: case study of Lagos state. Journal of Environmental Science and Water Resources. 2014; 3(7):145-148

12. Davies J, Foxall G R, Pallister J. Beyond the intention-behavior mythology: an integrated model of recycling. Marketing Theory. 2002; 1: 29-113.

13. Swami V, Chamorro-Premuzi T, Snelgar R, Furnhamd A. Personality, individual differences, and demographic antecedents of self-reported household waste management /behaviours. J. Environ. Psychol. 2011; 31;21-26.

14. Pearson H C, Dawson L N, Radecki Breitkopf C. 
Recycling attitudes and behavior among a clinicbased sample of low-income Hispanic women in southeast Texas. PLOS ONE. 2012; 7 (4): 1-6.

15. Sujauddin M, Huda S M S, Hoque A T M R. Household solid waste characteristics and management in Chittagong, Bangladesh. Waste Manage. 2007; 28 (9):1688-1695.

16. Ferrara L, Iannace M, Patelli A M, Arienzo M. Geochemical survey of an illegal waste disposal site under a waste emergency scenario (Northwest Naples, Italy) Environ. Monit. Assess. 2013; 185:2671-2682.
17. Brender J D, Maantay J A, Chakraborty J. Residential proximity to environmental hazards and adverse health outcomes. Am J Public Health. 2011;101(S1):37-52

18. UNEP. Towards a Green Economy: Pathways to Sustainable Development and Poverty Eradication, United Nations Environment Programme, Nairobi, Kenya. 2011.

19. Marshall R E and Farahbakhsh K. Systems approaches to integrated solid waste management in developing countries. Waste Manage. 2013; 33 (4): 988-1003. 
Table1: Socio demographic variables of respondents

\begin{tabular}{|c|c|c|}
\hline Variables & Sub variables & Frequency $(\%)$ \\
\hline \multirow[t]{5}{*}{ Age } & $15-24$ & $17(4.8)$ \\
\hline & $25-39$ & $144(41.0)$ \\
\hline & $40-64$ & $135(38.5)$ \\
\hline & 65 and above & $55(15.7)$ \\
\hline & Mean age & $43.61 \pm 16.02$ \\
\hline \multirow[t]{2}{*}{ Gender } & Male & $81(23.1)$ \\
\hline & Female & $270(76.9)$ \\
\hline \multirow[t]{3}{*}{ Marital Status } & Single & $54(15.4)$ \\
\hline & Married & $294(83.8)$ \\
\hline & Divorced & $3(0.8)$ \\
\hline \multirow[t]{3}{*}{ Religion } & Christianity & $74(21.1)$ \\
\hline & Islam & $259(73.8)$ \\
\hline & Traditional & $18(5.1)$ \\
\hline \multirow[t]{2}{*}{ Education } & No education & $70(19.9)$ \\
\hline & At least primary education & $281(80.1)$ \\
\hline \multirow[t]{2}{*}{ Occupation } & Unskilled & $30(8.5)$ \\
\hline & Skilled & $321(91.5)$ \\
\hline \multirow{3}{*}{$\begin{array}{l}\text { Average monthly } \\
\text { income }\end{array}$} & $=\mathbb{N} 9,900$ & $164(46.7)$ \\
\hline & 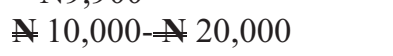 & $143(40.7)$ \\
\hline & ₹ 21,000 above & $44(12.6)$ \\
\hline
\end{tabular}

Table 2: Concerns of respondents towards improper solid waste management

\begin{tabular}{lll}
\hline Variable & Responses & Frequency (\%) \\
\hline Negative effect on natural resources & Yes & $294(83.8)$ \\
& No & $57(16.2)$ \\
Presence of waste in the neighborhood & Yes & $342(97.4)$ \\
& No & $9(2.6)$ \\
Health risk related to open burning & Yes & $330(94.0)$ \\
Flooding due to blocking of drainage & No & $21(6.0)$ \\
& Yes & $328(93.4)$ \\
Pollution of water bodies & No & $23(6.6)$ \\
Reduction of aesthetic value of the environment & Yes & $317(90.3)$ \\
Offensive odor & No & $34(9.7)$ \\
Animal bites & No & $274(78.1)$ \\
& Yes & $341(21.9)$ \\
& No & $10(2.8)$ \\
& Yes & $298(84.9)$ \\
& No & $53(15.1)$ \\
\hline
\end{tabular}


Table 3: Willingness of respondents to partake in organized solid waste management

\begin{tabular}{lll}
\hline Variables & Responses & Frequency (\%) \\
\hline $\begin{array}{l}\text { Will you be willing to participate in organized } \\
\text { waste management practices? }\end{array}$ & Yes & $248(70.7)$ \\
& No & $103(29.3)$ \\
Will you be willing to separate your waste? & Yes & $159(45.3)$ \\
& No & $192(54.7)$ \\
Will you be willing to pay for solid waste & Yes & $247(70.4)$ \\
collection from your household? & No & $104(29.6)$ \\
& & 9 (not willing to pay) \\
How much are you willing to pay per month? & $100-1000$ & $99(28.2)$ \\
& $1010-2000$ & $250(71.2)$ \\
& $2010-3000$ & $1(0.3)$ \\
\hline
\end{tabular}

Table 4: Self-reported health outcomes of respondents

\begin{tabular}{llll}
\hline S/N & Variables & Responses & $\begin{array}{l}\text { Frequency } \\
(\%)\end{array}$ \\
\hline \multicolumn{2}{l}{$\begin{array}{l}\text { Which of the following diseases have you? } \\
\text { experienced in the last six months? }\end{array}$} & \\
\hline 1 & Malaria & Yes & $249(70.9)$ \\
& & No & $102(29.1)$ \\
2 & Typhoid & Yes & $106(30.2)$ \\
& & No & $245(69.8)$ \\
3 & Vomiting without fever & Yes & $292(83.2)$ \\
& & No & $59(16.8)$ \\
4 & Skin infections & Yes & $94(26.8)$ \\
& & No & $257(73.2)$ \\
5 & Diarrhea & Yes & $97(27.6)$ \\
& & No & $254(72.4)$ \\
6 & Respiratory infections & Yes & $76(21.7)$ \\
& & No & $275(78.3)$ \\
\cline { 2 - 4 }
\end{tabular}


Table 5: Relationship between selected socio-demographic factors and practices of respondents

\begin{tabular}{|c|c|c|c|c|}
\hline \multirow[t]{2}{*}{ Variables } & \multirow[t]{2}{*}{ Sub-variables } & \multicolumn{2}{|c|}{ Practices } & \multirow[t]{2}{*}{$\mathrm{X}^{2}$ (P-value) } \\
\hline & & Poor (\%) & Good (\%) & \\
\hline \multirow[t]{2}{*}{ Gender } & Male & $55(67.9)$ & $26(32.1)$ & \multirow[t]{2}{*}{$7.217 \quad \mathbf{( 0 . 0 0 7 )}$} \\
\hline & Female & $221(81.9)$ & $49(18.1)$ & \\
\hline \multirow[t]{2}{*}{ Occupation } & Unskilled & $259(80.7)$ & $62(19.3)$ & \multirow[t]{2}{*}{$29.034(\mathbf{0 . 0 0 2})$} \\
\hline & Skilled & $17(56.7)$ & $13(43.3)$ & \\
\hline \multirow{3}{*}{$\begin{array}{l}\text { Average monthly } \\
\text { income }\end{array}$} & $=\$ 9,900$ & $139(84.8)$ & $25(15.2)$ & \multirow[t]{3}{*}{$2.538 \quad(\mathbf{0 . 0 1 3})$} \\
\hline & $10,000-20,000$ & $108(75.5)$ & $35(24.5)$ & \\
\hline & 21,000 above & $29(65.9)$ & $15(34.1)$ & \\
\hline \multirow[t]{2}{*}{ Education } & No formal education & $64(91.4)$ & $6(8.6)$ & \multirow[t]{2}{*}{$12.140(\mathbf{0 . 0 0 2})$} \\
\hline & At least primary education & $212(75.4)$ & $69(24.6)$ & \\
\hline
\end{tabular}

Table 6: Relationship between categorized health outcomes and selected variables

\begin{tabular}{|c|c|c|c|c|}
\hline \multirow[t]{2}{*}{ Variables } & \multirow[t]{2}{*}{ Sub-variables } & \multicolumn{2}{|c|}{ Categorized Health outcomes } & \multirow{2}{*}{$\begin{array}{l}\text { Statistics } \\
\mathrm{X}^{2}(\mathrm{P} \text { value })\end{array}$} \\
\hline & & $\begin{array}{l}\text { No health } \\
\text { outcome (\%) }\end{array}$ & $\begin{array}{l}\text { At least one health } \\
\text { outcome }(\%)\end{array}$ & \\
\hline \multirow[t]{3}{*}{ Marital status } & Single & $7(13.0)$ & $47(87.0)$ & \\
\hline & Married & $84(28.6)$ & $210(71.4)$ & $2.870(0.054)$ \\
\hline & Divorced & $1(33.3)$ & $2(66.7)$ & \\
\hline \multirow[t]{2}{*}{ Occupation } & Unskilled & $7(23.3)$ & $23(76.7)$ & \\
\hline & Skilled & $85(26.5)$ & $236(73.5)$ & $17.236(0.708)$ \\
\hline \multirow[t]{3}{*}{ Income } & $=\mathbf{N} 9,900$ & $44(26.8)$ & $120(73.2)$ & \\
\hline & $10,000-20,000$ & $35(24.50$ & $108(75.5)$ & $43.891(0.776)$ \\
\hline & 21,000 above & $13(29.5)$ & $31(70.5)$ & \\
\hline \multirow[t]{2}{*}{ Practice } & $\mathrm{Bad}$ & $65(23.6)$ & $211(76.4)$ & $1.736(\mathbf{0 . 0 3 0 *})$ \\
\hline & Good & $27(36.0)$ & $48(64.0)$ & \\
\hline \multirow[t]{2}{*}{ Attitude } & Negative & $7(10.9)$ & $57(89.1)$ & $35.559(\mathbf{0 . 0 0 2} *)$ \\
\hline & Positive & $85(29.6)$ & $202(70.4)$ & \\
\hline
\end{tabular}

*Statistically significant at $p<0.05$

*Categorized health outcomes comprise of respondents who reported at least one health outcome versus those without any health outcome

Table 7: Predictive factors of categorized health outcomes using logistic regression

\begin{tabular}{|c|c|c|c|c|}
\hline $\begin{array}{l}\text { Predictor } \\
\text { variable }\end{array}$ & Reference variable & P-value & OR & $95 \% \mathrm{CI}$ \\
\hline Practice & Poor practice & 0.037 & 2.27 & $1.272-4.053$ \\
\hline Attitude & Negative attitude & 0.000 & 3.45 & $1.471-8.106$ \\
\hline
\end{tabular}




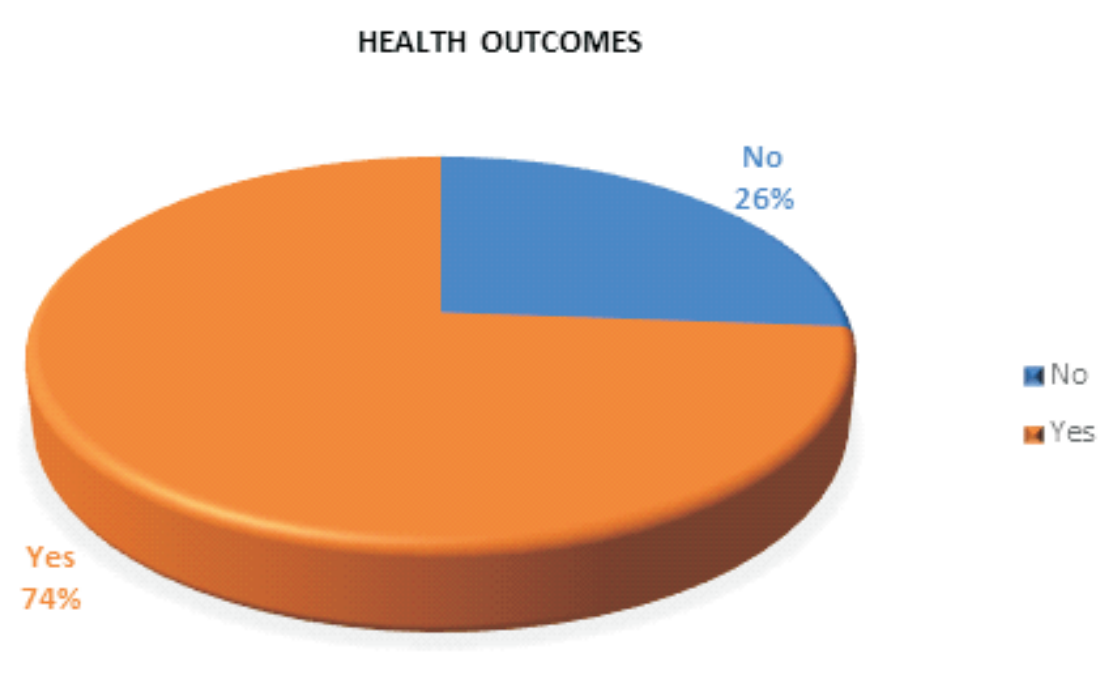

Figure 1: Categorized self-reported health outcomes

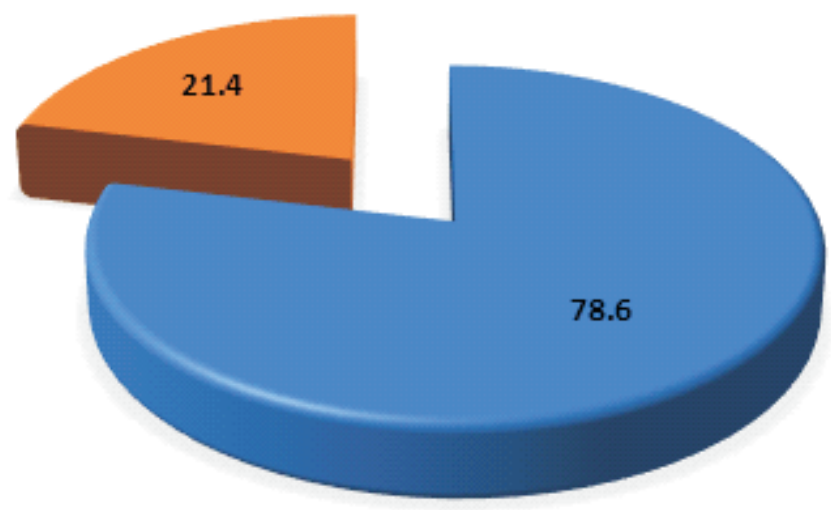

I POOR PRACTICES a GOOD PRACTICES

Figure 2: Categorized practices of respondents towards solid waste management

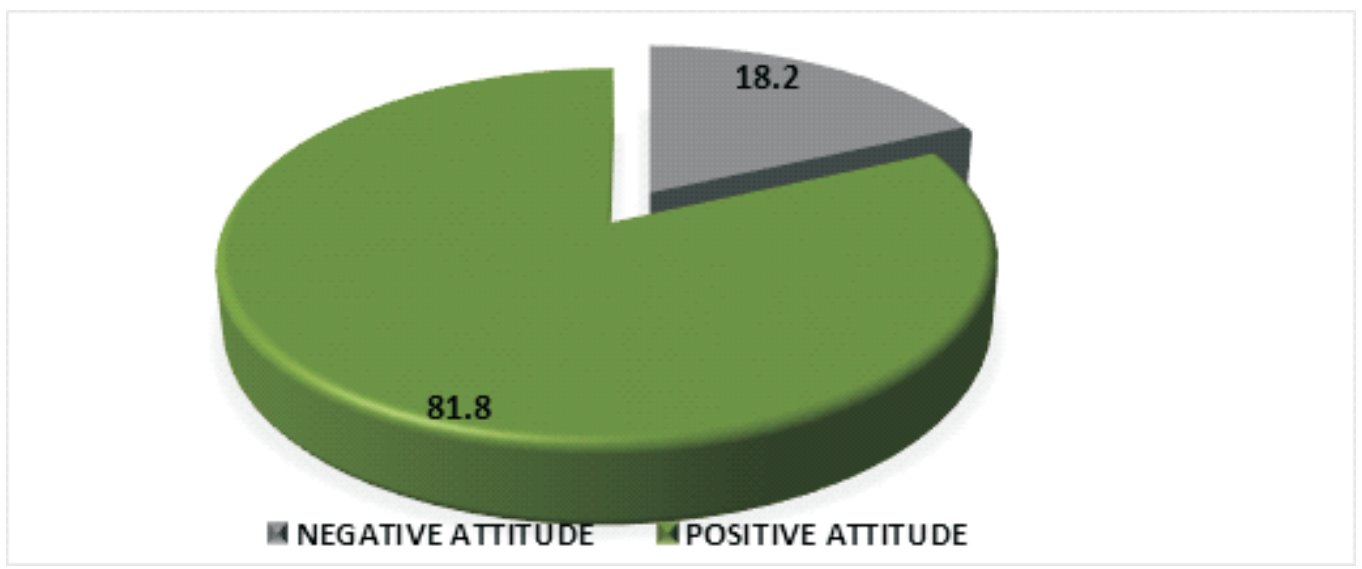

Figure 3: Categorized attitude of respondents towards solid waste management 